\title{
GONDOLATOK A TÚLHAJSZOLT CIVILIZÁCIÓRÓL RECENZIÓ BYUNG-CHUL HAN: A KIÉGÉS TÁRSADALMA CÍMÜ KÖNYVÉRŐL
}

\author{
A recenzió szerzője: \\ Baranyi Dániel \\ Eszterházy Károly Egyetem, Magyarország
}

A szerző e-mail címe:

baranyidanielmartin@gmail.com

\author{
Lektorok: \\ Trautmann László (Ph.D.) \\ Budapesti Corvinus Egyetem
}

Baranyi Dániel (2021): Gondolatok a túlhajszolt civilizációról. Recenzió Byung-Chul Han: A kiégés társadalma című könyvéről. OxIPO - interdiszciplináris tudományos folyóirat, 2021/1, 133-138 doi: 10.35405/OXIPO.2021.1.133
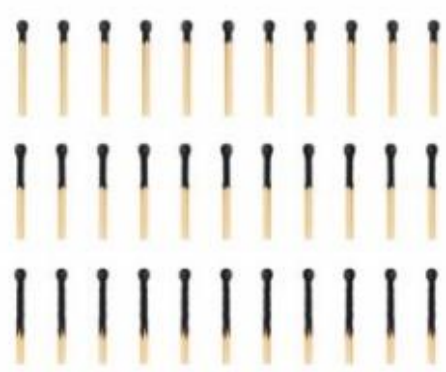

A KIÉGÉS TÁRSADALMA BYUNG-CHUL HAN
Jelen recenzió alapjául szolgáló mü bibliográfiája:

Byung-Chul Han (2019): A kiégés társadalma. Typotex Kiadó, Budapest ISBN: 9789634930655

Kulcsszavak: kiégés, társadalom

Diszciplínák: szocológia, filozófia

Bibliography of the subject of this recension:

Byung-Chul Han (2019): A kiégés társadalma /The Burnout Society/. Typotex Kiadó, Budapest

ISBN: 9789634930655

Keywords: burnout, society

Disciplines: sociology, philosophy 
Az elmúlt években több könyv is megjelent, amely azzal az igénnyel lépett fel (hol explicit módon, máshol a sorok közt), hogy megteremtse a kapcsolatot a társadalomtudomány ágai között. Az egyén és a társadalom közti dichotómia a filozófia klasszikus nagy kérdéskörei közé tartozik, azonban a XX. század második felének tudományossága és az objektivitásra való törekvés ezt a kérdést háttérbe szorította. A résztudományok merev elhatárolása által ennek vizsgálata kikerült a tudományágak művelőinek látóköréből. Az utóbbi évtized örvendetes trendje, hogy a határokat jelentő axiómarendszerek felülvizsgálata iránt növekvő érdeklődés mutatkozik. Az általam ismertetett könyv Byung-Chul Han: A kiégés társadalma címmel is ebbe a trendbe illeszkedik. A könyv célja, hogy a gazdaság és társadalom működését összekösse az egyének mentális és fizikai jólétével.

\section{Szabadság $\neq$ korlátok nélküliség}

A szerző abból indul ki, hogy napjaink társadalma ún. teljesítményelvű társadalom. Az ezt megelőző fejlődési szint a fegyelmező társadalom volt. A Han által teljesítményelvünek nevezett társadalom egészen más mentális zavarokkal jár együtt, mint a fegyelmező társadalom járt. Míg az utóbbiban az elfojtáshoz kapcsolódó betegségek, tünetek voltak leginkább jellemzőek (gondoljunk Freud munkásságára), addig napjaink jellemző betegségei a depresszió, a nárcisztikus zavarok, kiégés és az ADHD. Ennek oka pedig gazdaság és társadalom működése, amelyre jellemző a teljesítményelv mindenhatósága és végnélkülisége - vélekedik Han.

A Han részletesen kifejti, hogy a fegyelmező társadalom sajátja: a kötelességek, tiltások elérésük és betartásuk esetén a beteljesedés élményével, (a felsőbb hatalom általi) gratifikáció élményével jutalmazzák az egyént. Ez volt az erkölcsi, engedelmes alany korszaka. A teljesítményelvű társadalomban nem a kötelességek és tiltások uralják a szubjektumok mindennapjait, hanem a vágy. Vágyakozás a folyamatos tökéletesedés, a mindig lehet jobban/egészségesebben iránt. Nem a kötelesség, hanem a szabadság és az önkéntesség fogalmak jellemzik napjainkat. A külső korlátokat leépítettük. A tudat külső kényszerek helyett belső vágyakozásának válik a rabjává, és önmagát zsákmányolja ki Han szerint. Ez a szabadság tehát látszólagos, hiszen a tudat saját kényszerességének a rabja.

\section{Immunizáció, hibridizáció, globali- záció}

A külső elnyomás és a belső önkizsákmányolás tekintetében párhuzamot von a szerző az orvostudomány paradigmái és a geopolitika között. A kétpólusú világrendben - írja Han - és az azt megelőző korszakokban egymástól markánsan elkülönülő erők csaptak össze és törekedtek egymás legyőzésére. Immunológiai 
szempontból pedig a korábbi korokban a járványok jelentették az egészségre a legnagyobb veszélyt. Mindkét esetben a Sajátot tagadó és veszélyeztető Más jelentette a kihívást.

A Másság azonban a geopolitikában a globalizációval eltűnik, Különbözoôséggé szelídül, amely immunreakciót már nem vált ki - állapítja meg a könyv. Az új dialektika nem a Sajátba behatoló és azt tagadó Másságról, majd annak viszont-tagadásáról (immunválasz) szól, ami negatív dialektika volt. A pozitív dialektika a pozitivitás túltengését jelenti. Az Ugyanaz, nem vált ki immunreakciót, hiszen, hiányzik belőle „az idegenszerűség tüskéje”. Egészségügyi példaként az elhízást és a kiégést említi Han, amik a túlcsordult Ugyanabból, a pozitivitás túltermeléséből és túlteljesítéséből fakadnak.

Han szerint a negativitás eltűnését társadalmi szinten a határok átjárhatósága, és a járványok, mint vezető halálokok visszaszorulása jelenti. A kétpólusú világrend helyébe a globalizáció lépett, amelyben már nincs fenyegető Más, beutazható, megtapasztalható a világ.

Nem mehetünk el amellett, hogy a COVID-19 vírushoz kötődő pandémia idején ezen megállapítások már-már anakronisztikusan hathatnak. Számos szerző, többek között Harari is arról értekezik, hogy a XX-XXI. században több emberrel végez a cukor, mint fegyverek, és ugyanez a megállapítás a járványokra vonatkozóan is. (Harari, 2020) Az megállapítható, hogy a korábbi, a kontinens lakosságának akár felével is végző pestisjárványokhoz a koronavírus-járvány nem mérhető. Mindezek mellett a kutatók a járványok fokozott közép- és hosszútávú veszélyeire egyre gyakrabban hívják fel a közvélemény figyelmét.

A Másság eltűnését Han a posztindusztriális társadalom szükségszerűségének tartja. Az ipari fegyelmező társadalom változatlan identitások mentén külsô imperatívuszok által múködtette a termelést. Napjainkban a felettes én, helyébe a vonzó és elérhetetlen ideális én lépett. Az ideális én folyamatosan tevékenységre sarkall, külső kontroll nélkül is, ezzel tökéletesítve a kizsákmányolást - véli Han. Az identitás pedig feloldódik, hiszen a Saját korlátlan, minden a része, a Különböző sem Más többé, minden Ugyanaz. Ha kiterjedése korlátlan, akkor viszont nincs alakja sem, így bármi lehet. Han szerint a fegyelmező korszak hisztériás beteg személyiségének morféja jellegzetes, korunk depressziós személyisége viszont alaktalan. A posztindusztriális társadalomban a termelés további fokozása a rugalmas személy által valósult meg, aki képes bármilyen szerepet, funkciót betölteni. Itt azonban - véleményem szerint - Han a posztindusztriális társadalom olyan fontos jellemzőit hagyja figyelmen kívül, mint a szolgáltatások előtérbe kerülése, valamint a tudás felértékelődött szerepe (mint a társadalmi együttmúködés, a munkamegosztás alapja). A 
könyv lényegében az ipari kapitalizmus utáni korszakot próbálja az ipari kapitalizmus fogalmaival leírni és értelmezni.

„A túlzásba vitt munka és teljesítmény az önkizsákmányolásban csúcsosodik ki. Hatékonyabb, mint a mások általi kizsákmányolás, hisz párban jár a szabadság érzetével. A kizsákmányoló egyben maga a kizsákmányolt is.”

\section{Vita activa vs. vita contemplativa}

Han alapján a korlátlanság és emiatt a végtelenség irányába történő kudarca és elégedetlenségre ítélt küzdelem, együtt jár a tevékeny életnek a vita acitvanak a kultuszával. Mai társadalmunk a folyamatos tevékenykedést, az aktív, és szûkebb gazdasági értelemben is hasznos cselekvést állítja normaként. Ez a norma pedig nem csak külső elvárás, hanem belső morális érték. Az egyén soha nem elégedhet meg, nincs gratifikáció - vélekedik Han. A kellene külső imperatívuszának helyébe a lehetséges belső csábítása és egyben kényszere lép. Ez a szüntelen aktivitási kényszer a fókuszált figyelem helyébe a folyamatos multitaskingot és vele a hiperfigyelmet helyezi - olvashatjuk a könyv megállapítását. A szerző szerint ez visszalépés az emberi civilizáció számára az állatvilág felé. Az állat a vadonban bármilyen szükséglet kielégítő tevékenysége közben, legyen az táplálkozás vagy akár a párzás, folyamatos hiperfigyelemre van kárhoztatva, hiszen, ha elmélyedne tevékenysége közben, könnyen más állatok zsákmánya, áldozata lehetne. Az emberiség kulturális értékteremtése hívja fel a figyelmünket Han - nem jöhetett volna létre a fókuszált szemlélődő figyelem képessége és lehetősége nélkül. A fókuszált figyelemhez szükséges volt, hogy önnön fenntartásunk mellett lehetőségünk volt unatkozni és így nem szükségszerű tevékenységet végezni. A szemlélődő, fókuszált figyelem, mely nem a szükséges elvégzéshez kapcsolódik, vezetett a filozófiához is. Han példájával: a tánc a séta közbeni unalom terméke, ugyanakkor nem jöhetett volna létre, ha a sétára kizárólag a menekülés vagy éppen alapvető szükségletek kielégítése miatt lett volna szükség. Ha csak többet, vagy gyorsabban gyalogolunk (mintegy optimalizálva a szükségletkielégítésünket), az minőségileg nem új. A tánc az elmélyült szemlélődés nem szükséges eredménye. Az unalom együtt jár a kontempláció lehetőségével. Az unalom, Han szerint, nem összeegyeztethető tevékeny ember ideájával. Az emberiség kultúrájának számos korszakában nagyobb megbecsülés övezte a szemlélődő embert, mint a tevékeny embert. Han többek között a teremtést követően megáldott 7. nap példáját (megpihenés napját, nem a tevékenykedés napja) és az antik görög filozófia szabadságeszméjét állítja szembe a vita activa normájával.

Úgy gondolom, a teljesítményelv szabadsággal történő szembeállítása mögött meghúzódik, hogy Han a teljesítmény 
fogalmát alaposan leszűkítve, céljától megcsonkítva használja. Az értéktöbbletfogalma a termelésnek azt a részét jelenti, amely nemcsak a folytonos újratermeléshez szükséges (ez a munkás létfenntartásának költsége, a klasszikus politikai gazdászok szerint), hanem tiszta jövedelemként megteremti a lehetőséget a nem szükeséges fogyasztásra is, ezáltal a mennyiségi bővülés minőségi fejlődésbe történő átcsapását tételezve és létrehozva a teljesítmény és a fejlődés közötti kapcsolatot. A klasszikus politikai gazdászok ezt a tiszta jövedelemnek a hatalom forrásának tartották. A teljesítmény minőségi fejlődéssel való kapcsolatáról a könyvben nem található értelmezés, a teljesítmény Hannál a végtelen bővülést jelenti, a végtelen bővülését ugyanannak, ugyanazon a színvonalon.

\section{Továbbgondolás lehetőségei}

Véleményem szerint a tevékeny és Saját korlátlan kiterjesztésének igáját nyögő ember képével Han a nyugati kultúrkör középosztályának problémáit próbálja körüljárni. Számos kultúra ezen vonásokat azonban nem vette át. Nem feledkezhetünk el arról, hogy nem mindenhol építették le a külső korlátokat és nem szűnt meg a Negativitás sem univerzálisan.

Han nem tesz javaslatokat, könyve nem jelent programot sem az egyén, sem a gazdaságpolitika számára. Javaslatként talán az ünnepekre/fennkölt idők szentségére vonatkozó sorait értelmezhetjük. A már ismert, a társadalom és egyén számára felvázolt alternatívákra sem reflektál. Érdemes lehet az olvasottakkal összevetünk a különböző 'slow mozgalmakat', melyek jelentős népszerűségre tettek szert az elmúlt évtized során. A közgazdaságtant pedig az ember szerepének és személyiségének komplexitása egyre jobban foglalkoztatja. Konkrét gazdaságpolitikai javaslatok is jelentek meg a túlhajszolt cselekvési kényszerrel kapcsolatban, gondoljunk a nemnövekedés elméletére vagy az alapjövedelemre és munkaidő csökkentésre irányuló javaslatokra. Az egyének szintjén pedig nagyon egybecseng a könyv üzenete a pszichoterápiában viszonylag új terápiás irány, a tudatos jelenlétre építő kognitív terápia lényegével (MBCT-mindfullness based cognitive therapy).

Nem tisztázza azt sem a szerző, hogy a globalizáció fogalmával milyen a kapcsolata. Az Idegensžerüség eltűnését leíró jelleggel megállapítja, és azt is, hogy ebből a Pozitivitás túltengése követkeqiik, azonban azt nem mondja ki, hogy ezt visszafordítandónak látja vagy éppen ellenkezőleg, a fenntarthatóság lehetőségét keresve világít rá hibáira. Az ebben való tájékozódásunkat a globalizáció és a neoliberalizmus fogalmak megfelelő szétválasztása segíthette volna, ezt azonban a szerző nem teszi meg. Globalizáció, neoliberalizmus és posztindusztriális hiperkapitalizmus fogalmakat használja, lényegében szinonimaként, véleményem szerint helytelenül. Éppen ez a tisztázatlan fogalmi viszony jelenthette az akadályát annak, 
hogy gazdag gondolati fonalaiból végül alternatívát, programot szőjön. Nem hirdethet fejlődést, ha a globalizáció a kapitalizmus végtelen kiterjedését jelenti csupán, nem hirdetheti a szabadság bővülését, ha számára az egyén fejlődése csupán a kapitalista kizsákmányolás belsővé tételét jelenti. Nem gondolom, hogy a könyv célja a teljesítmény elv általános negligálása és kritikája lenne, éppen ezért lett volna fontos a teljesítményelvű társadalom definiálása és leválasztása a neoliberalizmus fogalmáról, ahol valóban a teljesítmény mögött lévő normatív célrendszer háttérbe szorult, a tudomány (és a gazdaságpolitika) pozitivitását hirdetve. A teljesitmény, céljától megfosztva, a szabadsággal könnyen szembeállítható. Egyre gyorsabb újratermelési kényszerként értelmezve a fejlődéssel, a szabadság kiterjesztésével nem összeegyeztethető fogalomként jelenik meg Hannál. Ezért nem tartom szerencsésnek napjaink társadalmát teljesítményelvű társadalomként definiálni, ez lényegében ugyanaz a hiba, mint a neoliberalizmus társadalom képe, ami a piac önkényének, természeti törvényszerűségeinek alárendelt társadalmat írt le.

Összességében nagyon ajánlom a könyvet kiemelten a különböző társada- lomtudományok művelőinek. A tudományágak határainak újradefiniálásáról, valamint a normatív célokról való gondolkodás szempontjából mindenképpen értékes kérdéseket vet föl a könyv, olvasmányos formában. A folyamatos önfejlesztés, karrierépítés, self-branding, önmegvalósítás stb. kifejezéssel körülírt, a lassításért/pihenésért/elégedettségért bűntudatot ébresztő krónikusan időhiányos hétköznapi működésünk vizsgálatára is jó alkalmat teremthet Han gondolatainak értelmezése. A könyv által feltárt probléma velünk van és fájó, azonban a feloldáshoz, meghaladáshoz néhány ponton a szerzô fogalomkészletét érdemes tovább gondolnunk, hiszen a könyv fogalmi rendszerével a szerző sem tud javaslatokhoz, alternatív narratívához jutni. Végső soron pedig azt tanácsolom, hogy ne (csak) azért olvassuk, mert hasznos.

\section{Irodalom}

Harari, Y. N. (2020): Homo Deus - A holnap rövid története, Ford: Torma Péter, Animus Kiadó, Budapest ISBN: 9789633244975 